\title{
Educação em saúde a professores do ensino fundamental sobre doenças de pele de etiologia viral, parasitária e bacteriana
}

\author{
Health education for school teachers on viral, parasitary and \\ bacterial ethology skin diseases
}

\author{
Rosane Teresinha Fontana ${ }^{1}$ \\ Bruna Sasso Antunes² \\ Rozelaine De Fátima Franzin ${ }^{3}$
}

\section{Resumo}

Estudo descritivo, transversal e aplicado desenvolvido junto a 59 docentes de um município ao noroeste do estado do Rio Grande do Sul, cujo objetivo foi investigar os saberes de professores dos anos iniciais do ensino fundamental sobre as principais dermatoses de etiologia viral, parasitária e bacteriana e elaborar um material educativo sobre o tema, que contribua para a educação em saúde. Os dados foram coletados mediante um questionário autoaplicado e analisados por meio da estatística descritiva. Utilizou-se, como referencial teórico para alicerçar o estudo, informações do Ministério da Saúde, da Sociedade Brasileira de Dermatologia, entre outros autores de expressão na dermatologia sanitária. Foi possivel identificar um considerável conhecimento, por parte dos professores acerca das doenças investigadas, bem como seus meios de transmissão e formas de prevenção. No entanto, também foi possivel verificar algumas lacunas que podem ter

\footnotetext{
${ }^{1}$ Doutora em enfermagem. Docente na graduação e no mestrado em ensino científico e tecnológico na Universidade Regional Integrada do Alto Uruguai e das missões, campus Santo Angelo/RS

2 Médica no Instituro Federal Farroupilha/Santo Ângelo/RS. Mestre em ensino científico e tecnológico.

${ }^{3}$ Doutora em engenharia de produção. Docente na graduação e no mestrado em ensino científico e tecnológico na Universidade Regional Integrada do Alto Uruguai e das missões, campus Santo Angelo/RS.

Interfaces da Educ., Paranaíba, v.11, n.31, p. 474 - 500, 2020
}

ISSN 2177-7691 
implicações na promoção da saúde dos estudantes. As educações em saúde nas escolas têm uma potência que muitos profissionais da saúde e professores desconhecem, visto ser um espaço de construção de saberes, de dialogicidade e de relações.

Palavras chave: Dermatoses. Saúde de escolares. Educação em saúde. Professores de Ensino Fundamental.

\section{Abstract}

Descriptive, cross-sectional and applied study developed with 59 teachers from a municipality in the northwest of the state of Rio Grande do Sul, whose objective was to investigate the knowledge of teachers of the early years of elementary school about the main dermatoses of viral, parasitic and bacterial etiology. elaborate an educational material on the theme that contributes to health education. Data were collected through a self-applied questionnaire and analyzed using descriptive statistics. It was used as theoretical reference to support the study, information from the Ministry of Health, the Brazilian Society of Dermatology, among other authors of expression in health dermatology. It was possible to identify considerable knowledge by the teachers about the investigated diseases, as well as their means of transmission and prevention. However, it was also possible to verify some gaps that may have implications for the health promotion of students. Health education in schools has a power that many health professionals and teachers are unaware of, as it is a space for the construction of knowledge, dialogicity and relationships.

Keywords: Dermatosis. Health of school children. Health education. Elementary school teachers.

\section{Introdução}

No Brasil, no período entre 2012 e 2014, foram registradas 33.610 .036 internações no Sistema Único de Saúde. Dessas, 1.889 .658 (5,6\%) foram de crianças e adolescentes (de zero a 19 anos) hospitalizados por Condições Interfaces da Educ., Paranaíba, v.11, n.31, p. 474 - 500, 2020 
Rosane Teresinha Fontana, Bruna Sasso Antunes e Rozelaine De Fátima

Franzin

Sensiveis à Atenção Primária (CSAP), sendo que, somente no ano de 2013, o número de internações para dez mil habitantes na população de zero a dezenove anos de idade foi de 168,7. Entre os principais motivos de internação, de acordo com os grandes grupos de CSAP, nos indivíduos de cinco a nove anos de idade, os principais diagnósticos foram asma (40,7\%), epilepsias (14,0\%) e infecções da pele e tecido subcutâneo (13,6\%). Na faixa de dez a quatorze anos de idade predominaram as internações por asma $(20,9 \%)$, infecções de pele e tecido subcutâneo $(16,8 \%)$ e epilepsias $(15,9 \%)$ (DIAZ, 2016).

O cenário da dermatologia na saúde pública tem uma importante relevância e isso é verificado pela presença de algumas doenças dermatológicas entre as queixas mais comuns na Atenção Básica, o que é apresentado nos Cadernos de Atenção Básica do Ministério da Saúde, em seu segundo volume, relativo ao Acolhimento à Demanda Espontânea, publicado no ano de 2012. Esse é um material que apresenta ofertas de abordagem de situações comuns no acolhimento à demanda espontânea, utilizando-se do saber clínico, epidemiológico e da subjetividade, por meio do olhar para riscos e vulnerabilidades, servindo como ferramenta auxiliar para a construção partilhada e cotidiana de modos de cuidar e gerir (BRASIL, 2012).

Sendo a escola um cenário estratégico para a promoção da saúde, uma vez que é um ambiente de aprendizado e de construção do conhecimento, a realização deste estudo se justifica pela importância desse espaço nas ações de prevenção das doenças e no auxílio a diagnósticos precoces. Esses fatores são essenciais para o bloqueio da transmissão, bem como para a diminuição da morbidade e da mortalidade, sendo uma ferramenta para a melhoria da saúde pública.

Considerando a necessidade de dados mais pontuais sobre esse tema, a proposição desta pesquisa, dentre seus objetivos, consistiu em analisar o conhecimento dos professores dos anos iniciais do ensino fundamental sobre dermatoses, apontando para uma referência nesse sentido. Com base nessa investigação, foi elaborada uma tecnologia educacional com informações 
relacionadas às fragilidades de conhecimento e saberes de docentes sobre o tema.

A proposta deste estudo poderá contribuir para ampliar os conhecimentos de estudantes e docentes com vistas à promoção da saúde e o consequente fortalecimento da educação em saúde, importante ferramenta de sensibilização, tanto individual como coletiva, de responsabilidades e direitos à saúde, proporcionando articulação entre todos os níveis de gestão do sistema. Envolve a integração entre saberes científico e do senso comum, admitindo uma visão crítica, participativa e autônoma, auxiliando no desenvolvimento de indivíduos criativos, livres e capazes de transformar a realidade social. Assim, educar em saúde não se restringe a apenas repassar informações, mas também sensibilizar a comunidade a respeito dos agravos à saúde, orientando práticas educativas que envolvam os sujeitos nas ações, para que se sintam participantes ativos da preservação de sua própria saúde

Diante desse contexto, esta pesquisa emergiu do seguinte questionamento: quais os saberes de professores dos anos iniciais do ensino fundamental, sobre doenças dermatológicas transmissiveis?

Assim, o objetivo geral do estudo foi investigar os saberes de professores dos anos iniciais do ensino fundamental sobre as principais dermatoses de etiologia viral, parasitária e bacteriana e elaborar um material educativo que contribua para a educação em saúde.

\section{Metodologia}

Estudo do tipo descritivo, transversal, aplicado. Foi realizado em 16 escolas municipais de ensino fundamental do perímetro urbano de um município da região noroeste do estado do Rio Grande do Sul, no primeiro semestre do ano 2018. Todas as escolas da rede municipal de ensino, do perímetro urbano, foram convidadas a participar.

Participaram do estudo 59 professores dos anos iniciais do ensino fundamental de um universo de 126 docentes que se enquadravam nos critérios para a participação: estar em trabalho ativo no quadro funcional das escolas municipais de ensino fundamental do referido município e ser professor de séries iniciais dessas escolas. Foram excluídos 20 professores Interfaces da Educ., Paranaíba, v.11, n.31, p. 474 - 500, 2020 
Rosane Teresinha Fontana, Bruna Sasso Antunes e Rozelaine De Fátima

Franzin

que atuavam nas séries iniciais da rede de ensino fundamental do município por se encontrarem afastados por motivos de licenças ou férias.

Os dados foram coletados por meio de um questionário autoaplicado. Foram realizados encontros presenciais, conforme acordado com a direção das mesmas. Nessa etapa, a pesquisadora reunia-se com os professores, explicando a proposta e a forma de desenvolvimento da pesquisa. Após cada explanação, foram distribuídos os questionários, os quais foram respondidos em um período de 15 a 20 minutos e coletados em urnas específicas para cada estabelecimento. Para todos os participantes, foi solicitado que não fosse realizada nenhuma pesquisa durante a resolução do questionário.

O questionário abordou as principais doenças de pele de etiologia infecciosa, de importância epidemiológica e de interesse à saúde pública, bem como seus cuidados e meios de prevenção. As perguntas foram elaboradas pelos pesquisadores e estão alicerçadas nas informações do Ministério da Saúde, no Caderno de Atenção Básica n. 28, volume II, intitulado 'Acolhimento à demanda espontânea - Queixas mais comuns na atenção básica' (BRASIL, 2012). Optou-se por estudar as doenças dermatológicas agudas e transmissiveis, de etiologia viral, parasitária e bacteriana, por estarem entre as queixas mais comuns da atenção básica, segundo o referido Caderno, sendo elas: impetigo, herpes simples, varicela, herpes zoster, rubéola, escabiose, sarampo, eritema infeccioso, exantema súbito, escarlatina, erisipela e pediculose (BRASIL, 2012).

O tratamento dos dados foi feito pela estatística descritiva, utilizandose a distribuição da frequência que é uma forma de sintetizar e organizar os dados coletados, dispondo-os de forma clara e significativa, visando facilitar sua compreensão e evidenciar suas tendências significativas (FEIJOO, 2010). Os dados foram apresentados na forma de gráficos e tabelas discutidos com a literatura científica.

O estudo respeitou os preceitos éticos para as pesquisas envolvendo seres humanos e foi submetido ao Comitê de Ética de uma Universidade Regional local, tendo sido realizado somente após a aprovação, sob o parecer número 23.438.35. Ao gestor foi oferecida uma Declaração de Instituição Coparticipante referente à sua anuência à pesquisa e aos participantes foi Interfaces da Educ., Paranaỉba, v.11, n.31, p. 474 - 500, 2020 
oferecido um Termo de Consentimento Livre e Esclarecido, o qual foi assinado em duas vias, ficando uma com os pesquisadores.

A partir da análise das respostas do questionário, foi criada uma ferramenta de apoio educacional, um álbum seriado, que pode ser utilizado como recurso às atualização de conhecimento dos professores acerca das doenças de pele prevalentes em ambiente escolar, contribuindo para qualificá-los no exercício de sua profissão e no âmbito da cidadania. Esse recurso também pode ser usado para ações de educação em saúde nas unidades de Estratégias de Saúde da Família para orientar trabalhadores e usuários.

\section{Resultados e discussão}

As escolas onde a pesquisa foi desenvolvida se situam em diferentes bairros da cidade, abrangendo populações de niveis sociais e econômicos variados, atendendo a crianças na faixa etária média de seis a doze anos de idade.

Em geral os professores reconhecem a grande dificuldade na área de educação em saúde, principalmente junto aos pais e à comunidade e aceitaram positivamente a investigação, porém em uma das 13 escolas, a direção informou que os professores não participariam da pesquisa porque entendiam que o questionário possuía um conteúdo muito complexo e, por isso, não deveria ser aplicado a docentes e, sim, deveria ser dirigido a agentes comunitários de saúde. Em outra, embora a direção tenha demonstrado muito boa aceitação em relação ao estudo, relatando diversos casos de problemas de pele nos alunos, como surtos de doenças, os quais a escola precisou encaminhar à unidade de saúde do bairro, acompanhados dos pais, houve desinteresse de alguns educadores em participar da pesquisa, com a justificativa de que entendiam como uma "perda de tempo" responder ao questionário.

Essa situação pode ser considerada como um descaso desses docentes à prevenção de agravos e de promoção da saúde de seus alunos, no que concerne às doenças de pele de etiologia infecciosa. Considerando que era objetivo da pesquisa verificar os saberes dos professores sobre as doenças de Interfaces da Educ., Paranaíba, v.11, n.31, p. 474 - 500, 2020 
Rosane Teresinha Fontana, Bruna Sasso Antunes e Rozelaine De Fátima

Franzin

pele, incluindo a questão do cuidado e dos meios de prevenção, esse discurso causou estranheza, visto que o foco da pesquisa era justamente conhecer a percepção de professores, leigos no assunto, sobre o tema em estudo. Não havia a intenção de avaliar, mas, sim, de explorar seus conhecimentos, a fim de se obterem elementos para a elaboração de um material educativo.

Diante do questionamento sobre as doenças de pele mais comuns na escola, algumas considerações merecem destaque. A pediculose foi citada como a doença mais frequente na escola, seguida da varicela, em 30,5\% das respostas. A média de doenças de pele citadas como mais comuns girou em torno de 4,86 doenças, com dispersão de 32,69 casos de doenças e um desvio padrão de 5,71. O coeficiente de variação é de $117,5 \%$, denotando dados heterogêneos.

Uma pesquisa, em uma amostra de 10.851 alunos na faixa etária entre quatro e doze anos de idade, de 72 escolas municipais da cidade de Nova Iguaçu (RJ), demonstrou uma prevalência total de $37,07 \%$ de pediculose, com 50,02\% de prevalência em meninas e 20,55\% em meninos. Também foi constatado que a parasitose estava presente em crianças pertencentes a famílias de diferentes padrões sociais e que havia a presença de sofrimento e baixa qualidade de vida entre os acometidos (OLIVEIRA et al., 2017). Os autores desta pesquisa referem literatura escassa de estudos clínico-epidemiológicos sobre o tema, visto que a maioria advém de trabalhos de conclusão de curso, de difusão limitada.

Outro dado relevante do estudo em tela, se refere ao fato de que 10 pessoas $(17 \%)$ responderam que o sarampo é uma doença comum na escola, demonstrando um dado controverso, visto que não confere com a situação epidemiológica do município do estudo, embora o sarampo seja uma doença (re) emergente. Tal conjuntura demonstra lacunas nos saberes sobre saúde entre educadores. Um estudo realizado com professores dos anos iniciais do ensino fundamental de duas escolas públicas da rede municipal de ensino da cidade de Rio Grande (RS) demonstrou que as abordagens das questões de saúde no ambiente escolar são deficientes em sistematização, ações e práticas. Isso porque a realização de atividades com vistas a esses fins Interfaces da Educ., Paranaíba, v.11, n.31, p. 474 - 500, 2020 
ocorre de forma esporádica, normalmente diante de necessidades, não havendo incorporação do tema no cotidiano das práticas escolares (MARINHO; SILVA; FERREIRA, 2015).

No questionamento sobre saberes de professores sobre dermatoses de interesse sanitário e epidemiológico em crianças, sobre o impetigo $61 \%$ dos professores responderam que é uma infecção bacteriana superficial da pele, observada mais frequentemente em crianças. Quanto ao tempo de afastamento da escola, a maioria dos indivíduos considerou que a duração deve ser até o desaparecimento dos sintomas. Porém, em geral, não há necessidade de afastamento de ambientes escolares ou de trabalho, com exceção de surtos comunitários ou de casos disseminados da doença (DUNCAN, 2013).

Quanto às formas de transmissão, as respostas mais frequentes se referem a contato de pele (37\%), As respostas quanto às formas de transmissão do impetigo estão corretas em sua maioria, visto que as mãos são o meio mais importante para transmitir o impetigo e a fonte mais comum de propagação epidêmica são as lesões supurativas. A doença é transmitida por bactérias e não por vírus (apontado por 5\%), sendo que picadas de mosquito, traumas ou escoriações podem facilitar a inoculação das bactérias Staphylococcus aureus e Streptococcus beta-hemolitico do grupo A (BRASIL, 2012).

Quanto ao herpes simples, $81,5 \%$ dos respondentes entendem que a doença se caracteriza por uma lesão se caracteriza por pequenas bolhas (vesículas) acompanhadas de dor, queimação e/ou prurido, dado que confere com a literatura científica. Nas demais opções de resposta, 47,5\% afirmaram que o vírus tipo 1 acomete a boca e o vírus tipo 2 acomete a genitália; 56\% responderam que não é necessário afastamento da escola. O herpes simples é uma infecção de difícil controle devido a sua elevada transmissibilidade. (BRASIL, 2012). Considerado uma das infecções humanas mais comuns, podem ser causado por dois tipos de virus, os quais podem infectar de forma direta ou por meio de soluções de continuidade. Isso ocorre, principalmente, pelo contato direto com pessoas que apresentam lesões primárias ou recorrentes, sendo que a infecção pode ser transmitida sem a presença de Interfaces da Educ., Paranaíba, v.11, n.31, p. 474 - 500, 2020 
Rosane Teresinha Fontana, Bruna Sasso Antunes e Rozelaine De Fátima

Franzin

lesões, porém a maior probabilidade envolve a transmissão na presença de lesões ativas, quando a quantidade de vírus é muito maior. O vírus do tipo 1, pode permanecer viável em pele, roupas e plásticos, favorecendo a transmissão por contato não sexual como beijo na face ou compartilhamento de utensílios, podendo atingir mucosas oral, ocular, genital e anal, uma vez que os dois tipos do vírus podem ocasionar infecção genital. Já o vírus do tipo 2 tem seu contágio preponderantemente por relação sexual ou, também, em gestantes infectadas que podem transmitir para o bebê pelo canal do parto (AZULAY, 2013). Observou-se que mais da metade dos professores desconhece a transmissão genital do herpes, visto que os dois tipos do vírus podem ocasionar infecção genital, condição não citada nas respostas.

Em relação a varicela a resposta prevalente $(95 \%)$ foi de que a manifestação se dá por pequenas bolhas (vesículas) no corpo, podendo haver mal-estar geral e febre, demonstrando conhecimento significativo dos professores sobre a questão; Em relação à necessidade de afastamento da escola, 90\% responderam que é necessário. Nesse questionamento as respostas foram variadas, prevalecendo os períodos de sete dias (25\%).

Doença causada pelo vírus varicela zoster e transmitida por meio do contato com gotículas contaminadas suspensas no ar ou contato direto com o fluido das lesões, sendo muito contagiosa. O quadro clínico inicia com sintomas gerais como febre, mal-estar e mialgias, lesões máculo-papulares eritematosas que, geralmente, iniciam em couro cabeludo e face, progredindo para tronco e extremidades, seguindo com o surgimento de vesículas que podem variar de poucas a centenas. Quanto a esses sintomas, cabe dizer que as respostas dos participantes correspondem a essa descrição. As lesões antigas evoluem para pústulas e crostas, sendo que a presença de lesões em vários estágios evolutivos é o grande marco dessa enfermidade (BOLOGNIA; JORIZZO; RAPINI, 2011). Sobre a transmissão, a literatura demonstra que ocorre por meio de contato direto ou de secreções respiratórias, podendo, raramente, ocorrer por contato com lesões de pele (BRASIL, 2017).

Quanto ao herpes zoster, 49\% responderam que ocorre em decorrência da reativação tardia do vírus da varicela; 45,5\% responderam Interfaces da Educ., Paranaíba, v.11, n.31, p. 474 - 500, 2020 
que desconheciam a doença; 27\% responderam que geralmente há dor, queimação, "dormência” e aparecimento de vesículas; $27 \%$ responderam que a dor pode persistir por meses e até anos após a resolução do quadro, interferindo na qualidade de vida. Esses dados retratam conhecimento deficiente de cerca de metade dos professores sobre o herpes zoster. Em relação à necessidade de afastar da escola em caso de herpes zoster, 23,5\% responderam que deve haver afastamento prevalecendo o periodo conforme orientação médica (7\%).

Para 23,5\% dos professores, o contato com a pele é a principal forma de transmissão do herpes zoster, seguida da transmissão por vírus $(15,5 \%)$; a higiene (10\%) foi apresentada como a forma mais eficaz de prevenir a doença. O mesmo vírus causador da varicela pode ser reativado e viabilizar o surgimento do herpes zoster ("cobreiro"), conhecimento manifestado por muitos professores. Essa reativação do vírus da varicela se dá nos nervos cranianos e nos gânglios das raízes espinhais dorsais, ocorrendo, geralmente, décadas após a infecção primária, principalmente em indivíduos com sistema imunitário comprometido, havendo forte correlação entre a sua maior incidência e o aumento da idade. Acomete, principalmente, tórax e face, iniciando com sintomas de queimação e dor na área da pele correspondente ao nervo acometido. Ocorre, geralmente, de forma unilateral, sendo acompanhado de febre, calafrios, cefaleia e mal-estar, evoluindo com o surgimento de eritema, máculas, pápulas, vesículas e crostas, podendo levar a complicações importantes como a neuralgia pós-herpética, que é uma dor neuropática crônica que pode comprometer a qualidade de vida do indivíduo. (PORTELLA; SOUZA; GOMES, 2013).

Pessoas que apresentam herpes zoster são infectantes, tanto pelas lesões, como pelas secreções da nasofaringe, sendo os contatos suscetiveis a desenvolver varicela. Portanto, assim como nos casos de varicela, indivíduos que apresentam essa doença devem permanecer afastados da escola ou do trabalho por até 10 dias após o aparecimento do quadro cutâneo ou até que todas as lesões de pele estejam crostosas (DUNCAN, 2013). Os dados da pesquisa apontam que não há consenso entre os participantes sobre afastar ou não da escola o aluno acometido. Sobre a transmissão do herpes zoster, Interfaces da Educ., Paranaíba, v.11, n.31, p. 474 - 500, 2020 
Rosane Teresinha Fontana, Bruna Sasso Antunes e Rozelaine De Fátima

Franzin

as respostas estão parcialmente corretas, uma vez que o desenvolvimento dessa doença decorre da reativação do vírus da varicela, sendo observada, mais comumente, em pacientes com algum comprometimento imunológico.

Sobre a rubéola prevaleceu a resposta de que essa doença pode ocasionar complicações ao bebê quando ocorre em mulheres grávidas (83\%), enquanto $74,5 \%$ responderam que se manifesta por lesões na pele que podem ser acompanhadas de febre e mal-estar geral. Do total, 42,5\% responderam que a transmissão pode ocorrer antes de as lesões aparecerem e de cinco a sete dias após o aparecimento das lesões. Quanto ao afastamento da criança do ambiente escolar em caso de rubéola, 76\% responderam que tal conduta é necessária, com maioria por sete dias. Para os respondentes, o ar (27\%), a saliva (22\%) e o espirro (22\%) são as principais formas de transmissão da rubéola.

Conforme os dados da literatura, a rubéola é uma doença febril exantemática aguda, causada por vírus, altamente contagiosa e de curso, geralmente, benigno. Tem grande importância epidemiológica devido à síndrome da rubéola congênita que está associada a abortamento e graves malformações congênitas, como cardiopatias, catarata e surdez. A transmissão do vírus ocorre por contato direto de pessoa a pessoa por meio da dispersão de gotículas de secreções nasofaríngeas, podendo ocorrer, também, por meio da placenta de mães infectadas e, com menor frequência, a transmissão por contato com objetos contaminados. O quadro clínico apresenta lesões exantemáticas, com máculas e pápulas, com aspecto róseo e difuso, de distribuição craniocaudal, com duração de cerca de sete dias, sem apresentar descamação, podendo ser acompanhado de sintomas gerais como febre baixa, cefaleia, mal-estar e linfadenopatia. Os indivíduos infectados devem ser mantidos afastados de ambientes escolares ou de trabalho por cinco a sete dias após o aparecimento das lesões exantemáticas, o que compreende o período de transmissibilidade da doença (DUNCAN, 2013), conhecimentos manifestados por grande parte dos professores estudados, mesmo que parcialmente.

Sobre a escabiose, $74,5 \%$ dos participantes consideraram que as lesões podem ocorrer em qualquer parte do corpo; $74,5 \%$ apontaram que o Interfaces da Educ., Paranaíba, v.11, n.31, p. 474 - 500, 2020 
principal sintoma é a coceira, que piora à noite; 62,5\% afirmaram que vestimentas, toalhas e roupas de cama devem ser lavadas e passadas com ferro quente. Quanto à necessidade de afastamento da escola em caso de escabiose, 64,5\% julgaram ser necessário (até desaparecer os sintomas, na maioria). O contato com a pele é a principal forma de transmissão da escabiose, na opinião dos professores (39\%), salientando que a média ficou em 3,58, variação de 24,04 com desvio padrão de 4,9. O coeficiente de variação dos dados foi de 133,8\%, apontando dados heterogêneos. Segundo a maioria dos participantes $(42,5 \%)$, a higiene é o principal meio de prevenção da escabiose.

A escabiose ("sarna") é uma dermatose infecciosa muito frequente, provocada por um ácaro que é parasita exclusivo do homem, o qual consegue viver apenas por poucas horas em outros animais ou em fômites. A principal manifestação clínica é o prurido, o qual, geralmente, piora à noite devido ao aumento da temperatura corporal que facilita a movimentação do parasita na superficie cutânea. A transmissão se dá pelo contato cutâneo direto e prolongado com indivíduos parasitados, por meio de roupas de cama, toalhas ou outros fômites, bem como por contato sexual, sendo que, quanto maior o número de parasitas no hospedeiro, maior é a probabilidade de transmissão (TAVARES, 2013; BRASIL, 2012).

A grande maioria dos professores demonstrou conhecer a doença e sua transmissão. Toalhas e lençóis devem ser lavados com água na temperatura de, pelo menos, $60^{\circ} \mathrm{C}$; podem ser submetidos a máquinas de secagem ou de lavagem a seco. Os artigos não laváveis devem ser fechados em sacos plásticos durante, pelo menos, 72 horas, fato desconhecido por grande parte dos professores. Os indivíduos podem retornar à escola ou trabalho no período de um dia após o início do tratamento, sendo que as demais pessoas que convivem nesses ambientes não precisam ser tratadas, a não ser que apresentem sinais ou sintomas de infecção (TAVARES, 2013). As respostas citadas pela maioria dos professores, acerca da escabiose, estavam corretas.

Quanto ao sarampo, 88\% afirmaram que a doença se manifesta por febre, tosse persistente, irritação nos olhos, secreção nasal e aparecimento de manchas avermelhadas em todo o corpo e $79,5 \%$ responderam que é Interfaces da Educ., Paranaíba, v.11, n.31, p. 474 - 500, 2020 
Rosane Teresinha Fontana, Bruna Sasso Antunes e Rozelaine De Fátima

Franzin

necessário afastar o aluno da escola em caso de sarampo, conforme orientação médica. As respostas mais citadas foram tosse, espirro e fala (34\%) e contato físico (34\%),

Conforme referenciado na literatura, as manifestações do sarampo incluem febre alta, tosse, coriza, conjuntivite e exantema maculopapular generalizado de distribuição craniocaudal, sendo que o mesmo dura cerca de quatro a sete dias, terminando com uma descamação característica. Podem ocorrer, também, lesões esbranquiçadas na mucosa oral, as quais são patognomônicas da doença. Não existe tratamento específico para essa enfermidade, sendo utilizadas medidas sintomáticas e de suporte. Os indivíduos acometidos devem ser afastados de ambientes escolares ou de trabalho por um período de quatro a seis dias antes do aparecimento do exantema, até quatro dias depois (DUNCAN, 2013). Tais informações são parcialmente conhecidas pelos professores, uma vez que alguns referiram que a doença é causada pelo calor, situação que não procede, pois essa é uma doença transmissivel. Porém, para a maioria dos participantes (61\%), o que está correto. A forma de transmissão do vírus é por via respiratória, por meio de secreções orofaríngeas de indivíduo infectado (BRASIL, 2012). As respostas sobre o sarampo estão adequadas, em sua maioria.

Sobre o eritema infeccioso, $71 \%$ dos participantes desconhecem a doença; 30,5\% acreditam que pode haver um tipo de lesão na face conhecida como "face esbofeteada", além de febre baixa. Na indagação sobre a necessidade de afastar o aluno da escola em caso de eritema infeccioso, 22\% responderam que deve haver o afastamento (até desaparecerem os sintomas). Para a maioria dos professores (22\%), o eritema infeccioso é transmitido por contato físico. No início do quadro, cerca de sete a dez dias antes das manifestações cutâneas, podem surgir sintomas gerais discretos, como febre baixa, mal-estar, dores musculoesqueléticas e náuseas, sendo esse o período de maior transmissibilidade da doença. Após alguns dias surge o exantema, o qual inicia na face, configurando o aspecto denominado "face esbofeteada", Precisa de afastamento da escola ou trabalho, uma vez que não existe vacina para tal patologia (SAMPAIO; RIVITTI, 2014). Identificou-se conhecimento deficiente dos participantes sobre a doença, Interfaces da Educ., Paranaíba, v.11, n.31, p. 474 - 500, 2020 
visto que mais da metade desconhece a doença.

Sobre o exantema súbito, $76,5 \%$ responderam que desconhecem a doença; $27 \%$ responderam que a doença também pode ser chamada de roséola; 23,5\% responderam que a doença se manifesta por meio de manchas vermelhas na pele, acompanhadas de febre; $13,5 \%$ referiram ser necessário afastamento, até desaparecerem os sintomas. Dos pesquisados, $17 \%$ acreditam que a transmissão do exantema súbito se dá por meio da saliva e $12 \%$ não sabem. O exantema súbito, também conhecido como roséola infantum, é uma virose que desencadeia uma febre exantemática, a qual é muito comum em crianças, principalmente abaixo dos dois anos de idade, sendo transmitida por meio de secreções como a saliva. Apresenta febre alta por cerca de três a cinco dias, que pode desencadear quadros convulsivos; após esse período, há o surgimento de lesões exantemáticas de coloração rósea, que iniciam no tronco e pescoço, disseminando-se para outras áreas do corpo. O quadro cutâneo desaparece em cerca de um a dois dias. Após a resolução do quadro, pode haver reativação do vírus, o que ocorre, principalmente, em estados de imunossupressão. Essa doença, em geral, apresenta um curso benigno e a maioria dos casos não requer tratamento específico. Deve haver afastamento de escola ou trabalho por cerca de sete dias após o aparecimento das lesões na pele (BELDA; CHIACCHIO; CRIADO, 2014).

A transmissão do exantema súbito ocorre pelo contato com secreções de um portador assintomático (BRASIL, 2012). Observou-que que há lacunas no conhecimento dos participantes sobre a doença, o que é demonstrado, principalmente, pelo desconhecimento da doença por mais da metade dos docentes.

Quanto à escarlatina, 51\% afirmaram desconhecer essa doença; 40,5\% afirmaram que é causada por uma bactéria; Sobre a necessidade de afastamento da escola em caso de escarlatina, 32\% responderam que o aluno deve ser afastado, até desaparecerem os sintomas.A transmissão da escarlatina, segundo a maioria dos professores, ocorre por meio do contato físico $(13,5 \%)$ e pelo ar (12\%). A escarlatina é uma doença bacteriana transmitida pelo contato com secreções respiratórias e, também, pela Interfaces da Educ., Paranaíba, v.11, n.31, p. 474 - 500, 2020 
Rosane Teresinha Fontana, Bruna Sasso Antunes e Rozelaine De Fátima

Franzin

ingestão de alimentos contaminados. Ela é causada por toxinas da bactéria Streptococcus beta-hemolitico do grupo $A$, sendo que a principal porta de entrada é o trato respiratório superior (BELDA; CHIACCHIO; CRIADO, 2014), o que demonstra uma maioria de respostas corretas.

A maioria dos casos ocorre entre um e dez anos de idade, iniciando com alguma infecção bacteriana, como amigdalite ou faringite, acompanhada de sintomas gerais como cefaleia, mal-estar, anorexia, náuseas e febre alta. Após um período de 12 a 48 horas do início dos sintomas, há o surgimento do quadro cutâneo, caracterizado por um eritema (pele com aspecto róseo ou avermelhado) com a presença de pequenas lesões papulosas, acometendo todo o corpo, conferindo sensação de "lixa" ao toque, podendo, também, haver o aparecimento de lesões na lingua, caracterizadas como lingua "em framboesa" ou "em moranguinho (BOLOGNIA; JORIZZO; RAPINI, 2011; BRASIL, 2012). Há necessidade de afastar os indivíduos infectados de seus ambientes escolares ou de trabalho por, pelo menos, 24 horas após o início do tratamento (BOLOGNIA; JORIZZO; RAPINI, 2011), o que não é de conhecimento da maioria dos respondentes.

Sobre a erisipela os resultados mostram que $49 \%$ responderam que desconhecem a doença; 42,5\% responderam que a doença afeta principalmente os membros inferiores; 30,5\% afirmaram que é mais frequente após os 60 anos de idade; $22 \%$ responderam que o aluno não deve ser afastado até desaparecerem os sintomas. A maioria dos participantes afirmou que a doença é transmitida por meio de bactérias $(15,5 \%)$ e por meio de ferimentos na pele (15,5\%). A erisipela é uma infecção bacteriana superficial da pele com intenso comprometimento da circulação linfática. É caracterizada por uma região da pele que se apresenta dolorosa, endurecida, edemaciada, quente e avermelhada, o que confere um aspecto de "casca de laranja", podendo ser acompanhada de sintomas gerais como febre, malestar e calafrios. (DUNCAN, 2013). A maioria dos respondentes desconhece essa doença e, entre os que a conhecem, o conhecimento é limitado.

No questionamento acerca da pediculose, $84,5 \%$ afirmaram que a principal manifestação é a coceira intensa na cabeça; 35,5\% responderam que ocorre somente na cabeça; $15,5 \%$ alegaram que desconhecem a doença. Interfaces da Educ., Paranaíba, v.11, n.31, p. 474 - 500, 2020 
Este último dado pode ser devido ao nome científico da doença. Em relação à necessidade de afastamento da escola, 40\% responderam ser necessário, até a eliminação dos piolhos. Mais da metade dos professores (51\%) referiu que o contato físico é a principal forma de transmissão da pediculose.

A pediculose é considerada uma das principais ectoparasitoses infantis, sendo uma infestação causada por piolhos sugadores, podendo acometer couro cabeludo, região pubiana e outras partes do corpo. Mais de $60 \%$ dos participantes desconhecem a manifestação da doença em outras regiões, além da cabeça. A doença é caracterizada por prurido intenso, conhecimento demonstrado pela maioria dos professores, podendo desencadear infecção secundária e anemia. A transmissão ocorre de pessoa a pessoa, independentemente de classe social, sexo ou etnia, por meio de contato direto ou do compartilhamento de objetos, como escovas e bonés, entre outros, havendo uma maior prevalência entre crianças (NUNES et al., 2014).

De acordo com a Sociedade Brasileira de Dermatologia (2018), roupas e utensílios de pano pessoais usados nas últimas 48 horas devem ser lavados com água em temperatura acima de 60 graus Celsius e/ou secados em máquinas de secar roupas nas mais altas configurações de calor. Pediculicida tópico é um método efetivo para o combate a essa parasitose, além de pentear o cabelo molhado com pente fino, sendo rara a necessidade de cortar os cabelos de crianças acometidas. Manter escovas de cabelos submersas em água por 10 minutos é uma medida suficiente para matar o piolho presente nos utensílios contaminados. Pode ser necessário o uso de medicação oral e, igualmente, familiares ou comunicantes do doente devem ser investigados e tratados, se necessário.

A transmissão da pediculose ocorre por contato direto com pessoa infectada ou com objetos usados por essa pessoa. Nesse aspecto, a maioria das respostas correspondeu a essa afirmação, demonstrando o conhecimento dos professores acerca das formas de contágio da pediculose, que é uma das parasitoses mais comuns a se manifestarem no ambiente escolar (BRASIL, 2012).

Destaca-se a relevante prevalência de condutas corretas, tendo sido Interfaces da Educ., Paranaíba, v.11, n.31, p. 474 - 500, 2020 
Rosane Teresinha Fontana, Bruna Sasso Antunes e Rozelaine De Fátima

Franzin

apresentada uma baixa prevalência de respostas incorretas, bem como um número muito pequeno de professores que responderam desconhecer as condutas que devem ser tomadas diante da doença. Em todas as situações, os professores citaram, com mais frequência, a necessidade de orientar os pais/responsáveis a procurar atendimento médico, comunicar coordenação/direção da escola e afastar a criança da escola, o que são atitudes consideradas corretas, visto a vulnerabilidade da criança diante de uma doença transmissivel. Uma vez que a escola pode ser a fonte do risco infeccioso, ela pode, também, ser uma intercessora da proteção contra esses riscos e um canal de informação de qualidade, além de modeladora de novas condutas (CELESTINO Jr et al., 2017).

No intuito de sistematizar os dados é válido apresentar o percentual de conhecimento geral manifestado pelos professores acerca das doenças pesquisadas. Quando questionados se as conheciam, os professores demonstraram que, em geral, têm algum tipo de conhecimento.

Tabela 1 - Conhecimento das dermatoses

\begin{tabular}{lllll}
\hline Dermatose & Conhece $\mathrm{F}_{\mathrm{i}}$ & \multicolumn{1}{c}{$\%$} & Desconhece & $\mathrm{F}_{\mathrm{i}} \%$ \\
Impetigo & 40 & $68 \%$ & 19 & $32 \%$ \\
Herpes Simples & 57 & $96,5 \%$ & 2 & $3,5 \%$ \\
Varicela & 59 & $100 \%$ & 0 & $0 \%$ \\
Herpes Zoster & 33 & $55,5 \%$ & 26 & $45,5 \%$ \\
Rubéola & 56 & $95 \%$ & 3 & $5 \%$ \\
Escabiose & 55 & $93,5 \%$ & 4 & $6,5 \%$ \\
Sarampo & 58 & $98,5 \%$ & 1 & $1,5 \%$ \\
Eritema Infeccioso & 17 & $29 \%$ & 42 & $71 \%$ \\
Exantema Súbito & 14 & $23,5 \%$ & 45 & $76,5 \%$ \\
Escarlatina & 29 & $49 \%$ & 30 & $51 \%$ \\
Erisipela & 30 & $51 \%$ & 29 & $49 \%$ \\
Pediculose & 50 & $84,5 \%$ & 9 & $15,5 \%$ \\
Total & 498 & & 219 &
\end{tabular}

Fonte: Dados da pesquisa, 2018

A média dos professores que conhecem as dermatoses pesquisadas 
ficou em 41,5\% e dos que desconhecem 17,5\%. Aplicando o teste t- Student, em comparação, presumindo-se variâncias iguais, nas duas amostras com 12 elementos cada, verificou-se que existe diferença significativa dos que conhecem para os que não conhecem, com um nivel de 95\% de confiança. O teste $\mathrm{t}$ calculado deu 3,55 e o teste $\mathrm{t}$ tabelado deu 2,07. Esses dados permitem verificar que, das doze doenças citadas, em apenas três delas houve a preponderância do desconhecimento da doença. Isso demonstra que, em sua maior parte, os professores possuem algum grau de conhecimento a respeito das dermatoses em questão.

Por fim, algumas considerações podem ser tecidas quanto à transmissão e prevenção de algumas das doenças investigadas. Acredita-se que, no meio escolar, tais conhecimentos tenham implicações na prevenção de complicações e/ou surtos. Muitas respostas denotam conhecimentos que condizem com as evidências científicas sobre o tema. No entanto, é importante salientar que, na maioria das respostas, a alternativa 'não sei' apareceu de forma recorrente, denotando um desconhecimento total, por parte de alguns professores, sobre as doenças.

As respostas das formas de transmissão de herpes simples, rubéola, sarampo e exantema súbito apresentaram bactérias como formas de transmissão, as quais são respostas equivocadas, visto que todas essas doenças são causadas por vírus, transmitidas por meio de contato e gotículas ou aerossóis. Ainda na abordagem sobre o sarampo, foi citada a transmissão pelo parto ou da mãe para o bebê, o que não é referenciado na literatura (DUNCAN, 2013).

Em relação ao herpes zoster, foi mencionada a transmissão por bactérias, por via sexual e que não é uma doença contagiosa. Tais respostas estão incorretas, uma vez que essa doença decorre da reativação do vírus da varicela, o qual, como já citado anteriormente, é transmitido por vias respiratórias ou, raramente, por contato com as lesões, não havendo evidências de transmissão sexual (BRASIL, 2012).

$\mathrm{Na}$ indagação acerca das formas de transmissão da escabiose foram citados vírus e bactérias, bem como transmissão pelo ar e que o ácaro é o parasita da varicela. Tais respostas estão equivocadas, posto que essa Interfaces da Educ., Paranaíba, v.11, n.31, p. 474 - 500, 2020 
Rosane Teresinha Fontana, Bruna Sasso Antunes e Rozelaine De Fátima Franzin

dermatose é causada por um ácaro, o qual não tem nenhuma relação com a varicela e é transmitido por meio de contato direto entre pessoas (AZULAY, 2013).

Sobre a erisipela e a pediculose igualmente foi citada a transmissão por vírus, pelo ar; no caso da pediculose, foi referido que também ocorre por meio de bactérias, demonstrando inadequação das respostas. A erisipela é causada por bactérias que penetram na pele por soluções de continuidade, como no caso de micoses interdigitais, não havendo participação de vírus no processo e não sendo transmitida pelo ar. Já a pediculose é a infestação por piolhos, que são parasitas humanos, e podem ser transmitidos por contato direto entre pessoas ou por meio do compartilhamento de objetos contaminados (BELDA; CHIACCHIO; CRIADO, 2014).

Quanto às respostas acerca das formas de prevenção das doenças, a análise aponta para o fato de que a maioria das concepções está em coerência com a literatura.

Tabela 2 - Formas de prevenção das dermatoses

\begin{tabular}{|c|c|c|c|c|c|c|}
\hline \multirow[t]{2}{*}{ Dermatose } & \multicolumn{2}{|c|}{ Correto $\mathrm{F}_{\mathrm{i}} \%$} & \multirow[t]{2}{*}{ Incorreto $F_{i}$} & \multicolumn{3}{|c|}{ Não sabe $F_{i}$} \\
\hline & & & & $\%$ & & $\%$ \\
\hline Impetigo & 51 & $82 \%$ & 7 & $11,5 \%$ & 4 & $6,5 \%$ \\
\hline Herpes Simples & 48 & $83 \%$ & 7 & $12 \%$ & 3 & $5 \%$ \\
\hline Varicela & 73 & $97 \%$ & 1 & $1,5 \%$ & 1 & $1,5 \%$ \\
\hline Herpes Zoster & 38 & $90,5 \%$ & 1 & $2,5 \%$ & 3 & $7 \%$ \\
\hline Rubéola & 59 & $91 \%$ & 5 & $7,5 \%$ & 1 & $1,5 \%$ \\
\hline Escabiose & 47 & $77 \%$ & 10 & $16,5 \%$ & 4 & $6,5 \%$ \\
\hline Sarampo & 63 & $98,5 \%$ & 0 & $0 \%$ & 1 & $1,5 \%$ \\
\hline Eritema & 39 & $76,5 \%$ & 7 & $13,5 \%$ & 5 & $10 \%$ \\
\hline \multicolumn{7}{|l|}{ Infeccioso } \\
\hline Exantema Súbito & 31 & $76 \%$ & 5 & $12 \%$ & 5 & $12 \%$ \\
\hline Escarlatina & 32 & $61,5 \%$ & 14 & $27 \%$ & 6 & $11,5 \%$ \\
\hline Erisipela & 45 & $79 \%$ & 7 & $12,5 \%$ & 5 & $8,5 \%$ \\
\hline Pediculose & 72 & $82 \%$ & 14 & $16 \%$ & 2 & $2 \%$ \\
\hline Total & 598 & & 78 & & 40 & \\
\hline
\end{tabular}


Fonte: Dados da pesquisa, 2018

Considerando as formas de prevenção das doenças e analisando as respostas corretas e incorretas, a média dos que responderam corretamente foi de 49,83\%. Percebeu-se que a grande maioria das respostas citadas como formas de prevenção das doenças está correta. Poucos participantes responderam desconhecer formas de prevenção das doenças em geral. Destacam-se as inferências sobre vacinas, visto que, nos últimos anos, a polêmica sobre as famílias que se negam a vacinar seus filhos tem invadido os debates públicos sobre saúde, considerando o importante crescimento do número de pais que optam por não permitir a aplicação de nenhuma vacina do calendário oficial.

Entretanto, algumas inadequações foram demonstradas, tais como a respeito do impetigo, já que foram citados como formas de prevenção uso de pomadas antibióticas, aplicação de vacinas e evitar lugares fechados. As principais medidas preventivas do impetigo envolvem hábitos de higiene, não sendo recomendado o uso profilático de antibioticoterapia tópica, assim como não há vacinas preventivas. De igual forma, a permanência em locais fechados não altera o curso da doença pelo fato de esta não ser transmitida por via respiratória (BELDA; CHIACCHIO; CRIADO, 2014).

$\mathrm{Na}$ prevenção do herpes simples, foi mencionado o uso de vacinas e evitar lugares fechados. Tais informações não são corretas, visto que não há vacina preventiva e a permanência em locais fechados não influencia na transmissão por esta não ser uma patologia transmitida por vias respiratórias (BRASIL, 2012).

Em relação à escabiose, foram citadas medidas preventivas como vacinas, uso de pomadas e cremes, manter higiene com animais de estimação e evitar contato com animais infectados. Tais respostas não estão corretas, visto que não há vacina preventiva para essa doença e o uso de pomadas e cremes não previne a contaminação, tendo seu uso reservado para tratamento. Em relação aos animais de estimação, o ácaro causador da escabiose em humanos não é o mesmo que acomete os animais e, portanto, não existe essa forma de transmissão (BRASIL, 2012).

$\mathrm{Na}$ abordagem da pediculose, foi mencionado o uso de vacinas, Interfaces da Educ., Paranaíba, v.11, n.31, p. 474 - 500, 2020 
Rosane Teresinha Fontana, Bruna Sasso Antunes e Rozelaine De Fátima Franzin

xampus, remédios caseiros e bonés. Essas respostas não são corretas, visto que não existe vacina que previna a infestação pelo parasita, assim como o uso dos produtos e objetos citados não é indicado como profilaxia, devendose, sim, manter bons hábitos de higiene e comportamento (DUNCAN, 2013).

\section{Considerações sobre o Álbum Seriado}

Diante da realidade da marcante presença das tecnologias no cotidiano das pessoas, considerando não apenas as tecnologias da informação e comunicação, mas, também, aquelas classificadas como independentes por não necessitarem de auxílios elétricos ou eletrônicos, a utilização desses recursos também deve estar presente nas escolas, uma vez que expande capacidades e amplia horizontes, sendo um apoio fundamental para um trabalho educacional transformador e de qualidade (POCHO et al., 2012).

Em vista disso e considerando a real necessidade de se ampliarem as formas de conhecimento sobre as dermatoses e de medidas preventivas que possam ser adotadas no sentido de inibir essas doenças, um dos objetivos deste estudo consistiu em fornecer um material educativo a fim de levar as informações necessárias às instituições escolares, sendo elaborado um álbum seriado, que é composto de um conjunto de folhas presas em um suporte, no qual o tema é apresentado com frases curtas, palavras-chave, ilustrações, histórias ou qualquer outra forma de representação que simbolize as ideias a serem trabalhadas de uma forma sintética e sequenciada (POCHO et al., 2012). O referido álbum aborda as principais doenças de pele transmissiveis de etiologia viral, parasitária e bacteriana, considerando aquelas de interesse sanitário, sua importância epidemiológica e possibilidade de transmissão na faixa etária pesquisada

Esse material constitui um portfólio de aproximadamente $21 \mathrm{~cm}$ de altura, com uma base horizontal que permite a utilização sobre uma mesa. Seu arquétipo está disponível no portal EduCAPES (ANTUNES; FONTANA, 2019). 
Figura 1 - Parte do arquétipo do álbum seriado

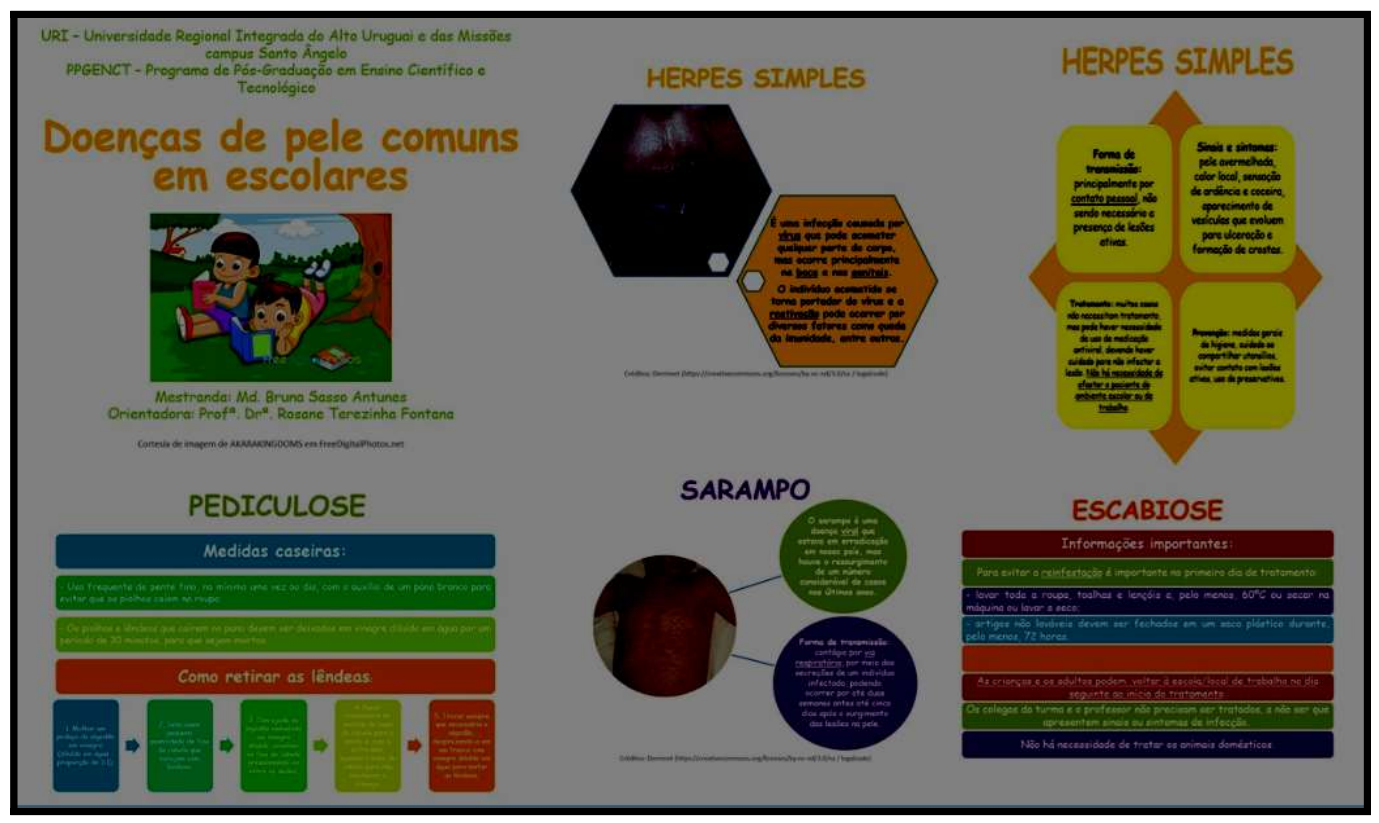

Fonte: os autores, 2019

\section{Considerações finais}

A análise dos dados permitiu a identificação de relevantes resultados. Destaca-se a percepção, por parte dos professores, da ocorrência de doenças de pele de etiologia viral, parasitária e bacteriana nas escolas, tendo sido citadas, respectivamente, a varicela, a pediculose e o sarampo. Dessas, a varicela e a pediculose são comuns na faixa etária estudada. No entanto, cabe observar que a informação de que o sarampo seja frequente é equivocada, visto que somente agora têm ocorrido novos casos da doença, antes erradicada. Um terço dos participantes referiu que o sarampo é uma doença frequente em nosso meio, informação que remete a uma importante reflexão.

Essa infecção viral está erradicada em nosso país desde o ano 2000, quando foi constatada a ausência de livre circulação do vírus em território 
Rosane Teresinha Fontana, Bruna Sasso Antunes e Rozelaine De Fátima

Franzin

nacional, havendo, desde então, apenas a confirmação de casos importados ou relacionados à importação. Uma vez que essa é uma doença de notificação compulsória no Brasil, o diagnóstico de qualquer caso requer a comunicação imediata às autoridades competentes, a fim de que sejam tomadas as medidas necessárias para a contenção de surtos. No município em estudo, não há dados epidemiológicos que demonstrem a presença dessa patologia nos últimos anos. Também foi apresentada, em relação ao sarampo, a afirmação de que pode ser causado pelo calor excessivo, o que é uma concepção histórica e errônea a respeito da doença, a qual, como já mencionado anteriormente, é causada por um virus.

Por conseguinte, identificou-se uma considerável desinformação a respeito de algumas doenças, tais como a inferência de que, durante o tratamento da pediculose o paciente deve permanecer com a cabeça enfaixada para não transmitir os "piolhos". Tal prática foi utilizada no passado e hoje é considerada totalmente desnecessária, posto que existe tratamento específico para essa doença, acessivel na rede pública de saúde. Deve-se ressaltar que o uso de tal método pode trazer um considerável constrangimento e discriminação dos indivíduos nas comunidades.

Importante destacar que a receptividade por parte dos professores, ao serem convidados a participar do estudo, tornou-se, inicialmente, uma limitação e uma preocupação na pesquisa. Alguns demonstraram desinteresse por necessitarem dispender tempo para responder aos questionários, apesar de, em sua maioria, haver um bom acolhimento aos pesquisadores nas escolas, principalmente por parte dos diretores, os quais se mostraram bastante interessados e preocupados com as questões de saúde de seus educandos.

Muito importante é destacar e refletir sobre o engajamento dos docentes na pesquisa. Tinha-se a estimativa de alcançar mais professores. Uma amostra de 59, de um total de 126 professores em atividade da rede municipal urbana de ensino, corresponde a menos da metade de participação $(46,8 \%)$ e pode ser um preditivo da importância atribuída às questões relativas à saúde do educando ou o despreparo dos professores, numa lógica de que esse assunto seria somente da competência da área da Interfaces da Educ., Paranaíba, v.11, n.31, p. 474 - 500, 2020 
saúde. Essa situação precisa ser discutida entre os profissionais da saúde e da educação, uma vez que a intersetorialidade e a interdisciplinaridade e atualmente a interprofissionalidade, podem trazer uma potência na educação para a saúde, o que, talvez, não seja dimensionado por esses profissionais.

Como limitações do estudo considera-se a falta de participação de todos os professores convidados, o que reforça o disposto anteriormente sobre a necessidade de se ampliarem as discussões sobre a importância de intervenção em saúde, bem como de os profissionais dessa área se integrarem aos professores a fim de refletirem sobre essas questões. Fica a sugestão de se ampliarem os estudos acerca da relação entre saúde e educação, pois somente assim as escolas poderão contribuir efetivamente para os cuidados e para a prevenção de doenças, entre as quais se destacam as dermatoses de etiologia viral, parasitária e bacteriana de importância sanitária e epidemiológica.

Sugerem-se estudos sobre o tema na área de abrangência de escolas de educação infantil e creches, que pela característica desta população, contatos físicos constantes, uso de chupetas, brinquedos à boca e compartilhadas entre os bebês, favorecem a transmissão de infecções.

\section{Referências}

ANTUNES, B.S.; FONTANA,R.T. Álbum seriado sobre doenças de pele de etiologia viral, parasitária e bacteriana, 2019. Disponivel em: https://educapes.capes.gov.br/handle/capes/433445 . Acesso em 16 jul 2019.

AZULAY, R. D. Dermatologia. 6. ed. Ed. Rio de Janeiro, RJ: Guanabara Koogan, 2013.

BOLOGNIA, J. L.; JORIZZO, J. L.; RAPINI, R. P. Dermatologia. 2. ed. Rio de janeiro: Elsevier, 2011.

BOSTON PUBLIC HEALTH COMMISSION | FACT SHEET. Eritema infeccioso. Fifth disease. Portuguese. March 2017. Disponivel em: Interfaces da Educ., Paranaíba, v.11, n.31, p. 474 - 500, 2020 
Rosane Teresinha Fontana, Bruna Sasso Antunes e Rozelaine De Fátima Franzin

<http://www.bphc.org/whatwedo/infectious-diseases/Infectious-DiseasesA-to-

Z/Documents / Fact\%20Sheet\%20Languages / Fifth\%20Disease/Portuguese.p df>. Acesso em: 20 out. 2018.

BRASIL. Ministério da Saúde. Secretaria de Atenção à Saúde. Departamento de Atenção Básica. Acolhimento à demanda espontânea: queixas mais comuns na Atenção Básica. Brasília: Ministério da Saúde, 2012. 290 p.

BELDA JUNIOR, W.; CHIACCHIO, N. D.; CRIADO, P. R. Tratado de Dermatologia. 2. ed. São Paulo: Atheneu, 2014.

CELESTINO JUNIOR, A. F. et al. Riscos infecciosos no ambiente escolar: relato de experiência com escolares através de metodologia ativa. Sau. \&Transf. Social, v. 8, n. 2, p. 128-34, maio-ago. 2017. Disponivel em: <http://www.redalyc.org/pdf/2653/265352024015.pdf>. Acesso em: 10 jun. 2018.

DIAZ, B. G. M. R. Internações de crianças e de adolescentes por condições sensíveis à atenção primária em saúde na rede pública de Porto Alegre/RS, no período de 2012 a 2014. 2016. 54f. Trabalho de Conclusão. Especialização em Saúde Pública. Faculdade de Medicina. Universidade Federal do Rio Grande do Sul. Porto Alegre, Rio Grande do Sul. 2016. Disponivel em: <https://lume.ufrgs.br/handle/10183/149372>. Acesso em: 15 out. 2017.

DUNCAN, B. B. et al. Medicina ambulatorial: condutas de atenção primária baseadas em evidências. 4. ed. Porto Alegre: Artmed, 2013.

NUNES, S. C. B. et al. Biologia e Epidemiologia da pediculose da cabeça. Scientia Amazonia, v. 3, n. 2, p. 85-92, maio-ago. 2014. Disponivel em: <http://www.scientia.ufam.edu.br>. Acesso em: 22 abr. 2018. 
FEIJOO, A. M. L. C. Distribuição de frequência. In: A pesquisa e a estatística na psicologia e na educação [online]. p. 6-13. Rio de Janeiro: Centro Edelstein de Pesquisas Sociais, 2010. Disponivel em: <http:/ / books.scielo.org/id/yvnwq/pdf/feijoo-9788579820489.pdf>. Acesso em: 03 set. 2017.

FERREIRA, I. do R. C. et al. Percepções de gestores locais sobre a intersetorialidade no Programa Saúde na Escola. Revista Brasileira de Educação. v. 19, n. 56, p. 61-76, jan.-mar. 2014. Disponível em: <http://www.redalyc.org/articulo.oa?id=27530123003>. Acesso em: 24 ago. 2017.

FERREIRA, V. F. et al. Educação em saúde e cidadania: revisão integrativa. Trab. educ. Saúde, Rio de Janeiro, v.12, n. 2, p. 363-78, ago. 2014. Disponível em: <http:/ /www.scielo.br/scielo.php?script=sci_arttext\&pid=S1981$77462014000200009 \& \operatorname{lng}=\mathrm{en} \& \mathrm{nrm}=\mathrm{iso} \& \mathrm{ln} \mathrm{ln}=\mathrm{pt}>$. Acesso em: 03 set. 2017.

MARINHO, J. C. B.; SILVA, J. A. da; FERREIRA, M. A educação em saúde como proposta transversal: analisando os Parâmetros Curriculares Nacionais e algumas concepções docentes. Hist. cienc. Saúde Manguinhos, Rio de Janeiro, v. 22, n. 2, p. 429-44, jun. 2015. Disponível em: <http://www.scielo.br/scielo.php?script=sci_arttext\&pid=S010459702015000200008\&lng=en\&nrm=iso\&tlng=pt>. Acesso em: 02 jun. 2018.

POCHO, C. L. et al. Tecnologia Educacional: descubra suas possibilidades na sala de aula. 7. ed. Petrópolis, RJ: Vozes, 2012.

PORTElla, A. V. T.; SOUZA, L. C. de B.; de; GOMES, J. M. A. Herpes-zóster e neuralgia pós-herpética. Rev. dor, São Paulo, v. 14, n. 3, p. 210-15, set. 2013. Disponivel em: <http://www.scielo.br/scielo.php?script=sci_arttext\&pid=S1806$00132013000300012 \& \operatorname{lng}=\mathrm{en} \& \mathrm{nrm}=$ iso $>$. Acesso em: 11 jun. 2018. Interfaces da Educ., Paranaíba, v.11, n.31, p. 474 - 500, 2020 
Rosane Teresinha Fontana, Bruna Sasso Antunes e Rozelaine De Fátima Franzin

RIBEIRO, C.; MENEZES, C.; LAMAS, C. Sarampo: achados epidemiológicos recentes e implicações para a prática clínica. Almanaque Multidisciplinar de Pesquisa. Universidade Unigranrio. ANO II. v. 1, n. 2, 2015. Disponivel em: <http:/ / www.faculdadeplus.edu.br/wp-content/uploads /2016/11/08Artigo-SARAMPO.pdf>. Acesso em: 11 jun. 2018.

SAMPAIO, S. A. P.; RIVITTI E. A. Manual de Dermatologia Clínica de Sampaio e Rivitti. 1. ed. São Paulo: Artes Médicas, 2014.

TAVARES, M.; SELORES, M. Escabiose: recomendações práticas para diagnóstico e tratamento. Nascer e Crescer, Porto. v. 22, n. 2, p. 8086 , abr. 2013. 